\title{
Understanding customer satisfaction in opera: first steps toward a model
}

\author{
Johanna Jobst* and Sabine Boerner ${ }^{\dagger}$ \\ Department of Politics and Management, University of Konstanz, Germany
}

\begin{abstract}
Despite the frequent call for a strengthened customer orientation in performing arts organizations, no efforts bave been made to investigate customer satisfaction in opera so far. The paper aims at filling this gap by suggesting a first integrative model of customer satisfaction in opera. This model integrates insights from both services marketing literature (i.e., general services marketing and performing arts marketing) and performing arts literature (i.e., music perception and theater studies). The model is tested in a field study interviewing 116 visitors of a public German opera house. Results reveal visitors' level of appraisal to be the main antecedent of their satisfaction, followed by their perception of the artistic quality, empathy/identification with the actors on stage, and recall from memory. Furthermore, differences within the audience regarding the relative importance of the antecedents of customer satisfaction in opera are investigated. Using gender and attendance frequency as segmentation variables, only minor differences are found, though. Managerial implications for opera marketing are discussed in conclusion. First, efforts in opera marketing should rather concentrate on the core service quality instead of the peripheral service quality. Second, professional opera companies may attract broader audiences if they focus on the emotional satisfaction of their customers. Third, since only minor and mostly insignificant differences between men and women, and occasional compared to frequent visitors are found, a need for further research to explore alternative segmentation variables in the opera context is identified.
\end{abstract}

\section{Introduction}

After decades of sustained growth, performing arts organizations are faced with costs rising faster than earned income, severe funding cuts from government sources, and changing philanthropic priorities among both corporations and foundations (Kotler and Scheff,

${ }^{*}$ Correspondence to: Johanna Jobst, University of Konstanz, Fach 88, 78457 Konstanz, Germany.

E-mail: johanna.jobst@uni-konstanz.de

Chair of Management (especially Strategy and Leadership).
2007). Due to additional tendencies such as demographic changes, changing leisure patterns, and declining leisure times, audience sizes tend to shrink (McCarthy et al., 2001), resulting in rising competition for customers' entertainment dollars. Hence, new efforts in audience development are strongly needed, including both expanding existing audiences and attracting new customers (Rentschler et al., 2002). Besides educational activities (e.g., Kawashima, 2000) and relationshipbuilding techniques (e.g., Walker-Kuhne, 2001), marketing efforts seem to be an 
appropriate approach for performing arts organizations to develop their audiences (Hill et al., 2004; Tajtákova and Arias-Aranda, 2008).

Performing arts organizations have been following the frequent call for a broadly based introduction of marketing instruments for a long time. However, focusing on subscribers, venue management, and attendance levels, these marketing efforts are hardly achieving performance objectives (e.g., Rentschler et al., 2002). Several reasons are made responsible. First, by collecting traditional demographic data (e.g., Sargeant, 1997), marketing approaches in the performing arts have concentrated on attendance, its antecedents, and attendance goals (e.g., Bouder-Pailler, 1999), while neglecting the effects of attendance on spectators. Second, they did not address the entire service offering, reaching from pre-arrival to post-departure. Third, factors influencing customers' repurchase intention such as their satisfaction levels have been disregarded. Fourth, performing arts marketing efforts concentrated to a great extent on "loyal arts enthusiasts" (Cuadrado and Molla, 2000), while loosing sight of a broader market definition, including potential visitors (Hume et al., 2006). Thus, in order to enhance audience development, performing arts organizations, first and foremost, must learn about customer satisfaction from prearrival to post-departure. In particular, they should focus on the determinants of customer satisfaction, looking at both their current and potential audience members, trying to find out "what people like and dislike, what they find attractive, what keeps them away" (Scheff and Kotler, 1996, p. 45; see also Gainer and Padanyi, 2002; Rentschler et al., 2002).

Research in services marketing has shown that customer satisfaction is an antecedent of customers' behavioral intentions such as loyalty intentions (e.g., Seiders et al., 2005) and repurchase intentions (e.g., Cronin and Taylor, 1992). Moreover, satisfaction predicts actual behavior outcomes such as customers' willingness to pay price-premiums (e.g., Cronin et al., 2000), positive word of mouth (e.g., Mittal et al., 1999), commitment (e.g., Hen-
ning-Thurau et al., 2002), and loyalty behavior (e.g., Gustafsson et al., 2005). Therefore, it is essential for the long-term survival of any organization in the services industry to effectively manage customer satisfaction. In order to do this, performing arts organizations need reliable information on the antecedents of customer satisfaction. However, while there is an extensive level of knowledge about customer satisfaction in the general services marketing literature, research on customer satisfaction in performing arts organizations is still scarce (Scollen, 2008).

Conducting in-depth interviews in the general performing arts context, Hume et al. (2006) found customer satisfaction to be one key driver of repurchase intention. By asking "What drives satisfaction for you at the performing arts?" several antecedents of customer satisfaction could be identified such as complimentary extras (e.g., refreshments, programs), the show experience, preferential or upgraded seating and ticketing, and exceptional personal treatment. In addition, main factors causing dissatisfaction were identified such as consistent service failure, poor accessibility, and excessive pricing. In an empirical study in a New York off-Broadway theater company, Garbarino and Johnson (1999) found overall satisfaction in theater to consist of satisfaction with the actors, preference for familiar actors, satisfaction with the play (e.g., diversity, interestingness, thought-provokingness), and theater facility satisfaction (i.e., physical setting). In a study on customer satisfaction in theater, Voss and Cova (2006) expected two types of quality contributing to customer satisfaction, that is, technical quality and functional quality. Whereas technical quality was described as the perceived quality of the core service, functional quality consisted of "perceptions of the manner in which the service is delivered" (Voss and Cova, 2006, p. 204). Surprisingly, the empirical results of the study did not show a direct link between the perceived quality of the core service and customer satisfaction. Post boc tests for mediation indicated that the tangible quality of the core service was important to the 
customers, "driving their engagement in elaboration of image attributes, but it is not important enough to directly stimulate satisfaction when other factors of the consumption experience are taken into account in complex encounters" (Voss and Cova, 2006, p. 201). Spectators' response to a theater performance was investigated by Bourgeon, who discovered perceptions of quality (production, acting, the play, the message), perceptions of the ambience as well as emotions to be determinants of theatergoers' satisfaction (Bourgeon cp. Kotler and Scheff, 2007, p. 190 et seq.). Asking visitors of a German community theater, Boerner et al. (in press) found spectators' perception of stage direction to be the main determinant of their overall enjoyment in theater, followed by their emotional response.

While some studies focused on customer satisfaction in theater, no efforts have been made to investigate visitors' satisfaction in the context of opera. However, opera has a considerable share of performances within the total performing arts (e.g., Deutscher Buehnenverein, 2006). Additionally, it is the most people- and cost-intensive performing art discipline (Vogel, 2001; Towse, 2003). The need to intensify customer orientation thus seems to be particularly urgent in opera companies. Therefore, the aim of our paper is to investigate customer satisfaction in opera.

In comparison to other performing art disciplines, two features of opera performances need to be considered. First, visitors' emotional response to the performance on stage is assumed to play a decisive role for their overall satisfaction in opera. While even singing alone is seen to be very prone to evoke strong emotional feelings in the listener, opera "adds all the emotional power of the dramatic plot and the personality of the protagonist" (Scherer, 1995 , p. 242). Second, opera integrates aspects of various performing art disciplines such as music, theater, and dance (Koebner, 1993; Eversmann, 2004). The result is a rather complex visual and acoustic experience (Boerner, 2002, 2004; Boerner and Jobst, 2008). Therefore, concepts developed to explain visitors' satisfaction with an evening in theater or in concert may be insufficient to cover the complexity of an evening in opera.

Against this background our paper suggests a first integrative model of customer satisfaction in opera, building on literature in services and performing arts marketing and integrating insights both from music perception and theater studies. This model will be tested in an empirical study with $n=116$ visitors of $\mathrm{W}$. A. Mozart's The Magic Flute performed at Dessau Opera House. The results of our study provide first answers to the following questions: (1) What are the antecedents of customer satisfaction in opera? (2) Are there differences within the audience regarding the relative importance that is given to the antecedents of customer satisfaction in opera?

\section{Conceptualizing customer satisfaction in opera}

In the services marketing literature, customer satisfaction has traditionally been conceptualized as a disconfirmation process (Lewis and Booms, 1983; Groenroos, 1984; Parasuraman et al., 1988). Hereby, customer satisfaction is seen to arise when customers compare their perceptions of a product's or service's performance with their expectations (created by past experiences, media reviews, word of mouth, advertising, etc.; e.g., Oliver, 1980; LaBarbera and Mazursky, 1983; Oliver and DeSarbo, 1988). If the perceived performance exceeds the customer's expectations, he/she is satisfied ("positive disconfirmation"); if the perceived performance falls below the expectations, the customer is dissatisfied ("negative disconfirmation"). However, both theoretical and empirical problems of this conception are discussed in literature. While Teas (1993), for example, listed conceptual problems, Spreng and Olshavsky (1992) hold that the disconfirmation model suffers from problems concerning the measurement of expectations. In addition, most of the studies testing the disconfirmation model found a poor fit with empirical data (Dabholkar et al., 2000).

Alternatively, customer satisfaction has been conceptualized as customer's fulfillment 
response. Oliver (1996, p. 12), for example, synthesizes prior definitions of customer satisfaction into the following:

Satisfaction is the consumer's fulfillment response. It is a judgment that a product or service feature, or the product or service itself, provided (or is providing) a pleasurable level of consumption-related fulfillment, including levels of under- or overfulfillment.

Measures of customer satisfaction relying on customer's level of fulfillment have achieved good predictive power (Dabholkar et al., 2000). We therefore define customer satisfaction in opera as pleasurable fulfilment, that is, the customer's sense that attending opera fulfills some needs, desires, or goals and that this fulfillment is pleasurable.

\section{An integrative model of customer satisfaction in opera}

We develop our model by linking two streams of research. In order to identify the antecedents of customer satisfaction in opera, we review the existing research in services and performing arts marketing for possible analogies. In addition, we integrate insights from both music perception and theater science in order to make allowance for the particularities of opera.

In accordance with Oliver (1993), we assume the service quality to be one key antecedent of customer satisfaction in opera. ${ }^{~}$

\footnotetext{
${ }^{1} \mathrm{~A}$ discussion in the services marketing literature has addressed the issue whether customer satisfaction and service quality are identical or different constructs (Dabholkar, 1995; Iacobucci et al., 1994; Oliver, 1993). Assuming them to be distinct raises the question of their causal relationship. For quite some time, researchers have seen customer satisfaction with a given service experience, that is, a transaction-specific satisfaction, leading to an overall evaluation about the provider's service quality (Bitner, 1990; Parasuraman et al., 1988). In contrast, Oliver (1993) was the first to suggest service quality to be an antecedent of customer satisfaction - regardless of whether the constructs were measured transaction-specific or over time. Several studies found empirical support for this suggestion (Anderson and Sullivan, 1993; Spreng and Mackoy, 1996).
}

In line with the literature on performing arts marketing (e.g., Anderson et al., 2008), we suggest the service quality in opera to consist of both the core service (i.e., what is delivered) and the peripheral service (i.e., bow it is delivered). Since the core service is "that part of the service we think of when we name the service" (Iacobucci and Ostrom, 1993, p. 258), we interpret the core service in opera to be the artistic performance on stage. The peripheral service, then, is everything besides the stage performance. Prior research in services (e.g., McDougall and Levesque, 2000; Butcher, 2005) and performing arts marketing (e.g., Guenter, 2001; Hausmann, 2007) showed that both the core service quality and the peripheral service quality are positively associated with customer satisfaction. In the following, we will outline these elements of our model, specifying visitors' perception of the core service and the peripheral service in opera.

With respect to the core service, we cannot refer to existing research neither in commercial marketing philosophy nor in (performing) arts marketing. A variety of conflicts between art/creativity on the one hand and business/ management on the other hand exists (DiMaggio, 1987; Auvinen, 2001; Eikhof and Haunschild, 2007). As a consequence, an adoption of commercial marketing in the arts scene is perceived as resulting in an increased risk of making artistic sacrifices and compromising the artistic mission. Therefore, it is rejected mostly. Caust (2003, p. 58), for example, warns against the adoption of a businesslike approach since it may lead to "the production of safe, consumer-oriented arts products which, in the end, may not be what the audience either wants or needs." As a consequence, existent customer satisfaction concepts in the performing arts (e.g., Kotler and Kotler, 1998; Colbert et al., 2001; Kotler and Scheff, 2007) exclude the core service, that is, the artistic product, from the marketing task. However, marketing efforts excluding the core service are not reaching far enough.

Satisfying customers and competing
within the entertainment industry are 
ways of raising attendance and revenue, but they do not necessarily generate the desired co-creative responses. Moreover, the arts marketing promise not to compromise the artistic mission does not go far enough. This promise must be replaced by the 'obligation' to contribute to the artistic mission (Boorsma, 2006, p. 77).

Rather, looking at the experiential marketing literature seems promising to get insights into opera visitors' perception of the core service. A visit to opera can be considered as experiential service, "which consumers choose, buy and use solely to experience and enjoy" (Cooper-Martin, 1991, p. 372). ${ }^{2}$ In contrast to traditional marketing, which views customers as rational decision-makers who mainly care about functional features and benefits, experiential marketing sees customers as rational human beings who are concerned with achieving pleasurable experiences. As a result, customers are expected to be both rationally and emotionally driven (Schmitt, 1999). Transferring findings from experiential marketing literature to the opera context, we suggest visitors' reaction to an opera performance to be both cognitive and emotional.

We interpret visitors' cognitive reaction as their rational evaluation of the artistic performance quality. In an intellectual game, visitors judge the artistic characteristics of the performance and derive pleasure from exercising their analytical skills (Eversmann, 2004). Hereby, visitors may evaluate the music dimension (e.g., orchestra, soloists) and the staging dimension (e.g., acting quality, scenery) as well as the congruency between these components (Boerner, 2002, 2004; Boerner and Jobst, 2008).

In order to further elaborate on visitors' emotional response to opera, we borrow and

\footnotetext{
${ }^{2}$ In contrast to functional products, which deliver more cognitively oriented benefits and fulfil utilitarian functions (Woods, 1960), the main benefit of experiential products is hedonic consumption, that is, feelings, emotions, and sensations experienced during product usage (Hirschman and Holbrook, 1982).
}

adopt insights from domains that share features with opera, namely music perception and theatre studies. Literature in music perception provides detailed insights into "aesthetic emotions" (Scherer, 2004) elicited by music. Similar to a multiplicity of studies (for a review, see Juslin and Sloboda, 2001), Scherer and Zentner (2001) identified three mechanisms "whereby emotion may be generated by music" (Scherer and Zentner, 2001, p. 365 ), that is, appraisal, recall from memory, and empathy. There is an emerging consensus among theorists that the elicitation of emotion "is best understood by assuming a process of event evaluation, or appraisal, that models the way in which an individual assesses the personal significance of an event for its wellbeing on a number of criteria and dimensions" (Scherer and Zentner, 2001, p. 366; emphasis added). Furthermore, recall from memory or imagination is identified as a central route to emotion induction. Music is shown to be very powerful in "bringing emotional experiences from memory back into awareness" (Scherer and Zentner, 2001, p. 369), and, thus, evoking similar emotional reactions as in the original experience. An additional mechanism is empathy, whereby emotions are elicited by "just observing another person being affected by an event that is very important to him or her but not necessarily to us" (Scherer and Zentner, 2001, p. 369). Here, the underlying mechanism is identification with the performer.

Similarly, theater studies confirmed appraisal (e.g., Konijn, 1999), recall from memory (e.g., Eversmann, 2004), and empathy/identification (e.g., Zillmann, 1994) to be relevant emotions arising during theater performances. Combining findings from research in music perception and theater studies, we thus expect customers' emotional responses to a performance in opera to be composed of appraisal, recall from memory, and empathy/identification.

Concerning the peripheral service, we refer to the services marketing literature, which divides the peripheral service into physical and interactional dimensions (Bitner, 1990; Chase 


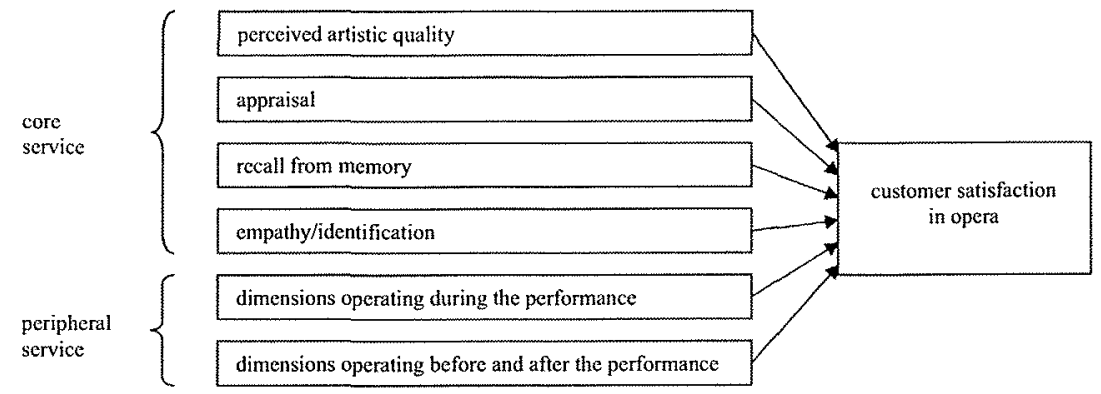

Figure 1. An integrative model of customer satisfaction in opera

and Stewart, 1994; Butcher et al, 2003). However, for the context of opera, we consider a temporal subdivision of the peripheral service to be more appropriate. A visit to opera consists of sequential stages, such as visitors' arrival at the venue, the stage performance, lingering within the venue both in the interval and after the performance, and visitors' departure. We therefore distinguish between dimensions operating during the performance and dimensions operating before and after the performance (Haefs and Schmidt, 1999).

To sum up, our integrative model includes the following antecedents of customer satisfaction in opera: (1) customers' cognitive perception of the core service, that is, the perceived artistic performance quality, (2) customers' emotional response to the core service, that is, the performance on stage segmented into level of appraisal, recall from memory, and level of empathy/identification, and (3) the perceived quality of the peripheral service - segmented into dimensions operating during the performance and dimensions operating before and after the performance (see Figure 1). According to this model, the following hypothesis on customer satisfaction in opera can be formulated:

Hypothesis 1. Customer satisfaction in opera is a function of the perceived artistic quality, customers' level of appraisal, recall from memory, level of empatby/ identification, dimensions operating during the performance, and dimensions operating before and after the performance.

\section{Differences in customer satisfaction in opera within the audience}

Already 30 years ago, DiMaggio et al. (1978, p. 5) claimed that a "major question of audience research is whether there is one audience or many." Accordingly, we do not know to what degree the model of customer satisfaction in opera depicted in Figure 1 can be regarded as universal or, on the contrary, susceptible to influences from different audience segments. Since visitors tend to differ in a variety of characteristics (Cooil et al., 2007; Anderson et al., 2008), differences in their perceptions of a performance in opera are likely, presumably resulting in different judgments on the same evening.

In the performing arts literature (Kotler and Scheff, 2007), three groups of variables are used for audience segmentation, that is, geographic (e.g., region, distance from the venue), demographic (e.g., age, income), and psychographic (e.g., lifestyle, personality). Although systematic efforts in segmenting theater audiences are lacking, gender and attendance frequency have been found to influence visitors' perception of the theatrical event. In their study of customer satisfaction in theater, Voss and Cova (2006) expected sex differences to be a key reason for individual 
differences in visitors' perceptions. They found functional quality attributes (e.g., customer's interaction with the service personnel) to be more important for the satisfaction of men than of women. Women, on the other hand, "report higher levels of satisfaction when they perceive that the theatre possesses pro-social values" (Voss and Cova, 2006, p. 213). Differences between men and women concerning their information processing strategy (e.g., Meyers-Levy and Sternthal, 1991) and their psychological orientation along the dimensions of agency (concerned with achievement, prominence, and success) and communion (concerned with interpersonal relationships, intimacy, and attachments; Watts et al., 1982) are made responsible. Applying these results to the field of opera, we expect differences between men and women regarding the relative importance of the individual antecedents of their satisfaction.

Hypothesis 2a. Men and women differ regarding the relative importance of the individual antecedents of customer satisfaction in opera.

Besides gender, differences between occasional and frequent theatergoers have been examined in the theater marketing literature. Kotler and Scheff (2007, p. 195), for example, assumed that "a first-time oper" agoer will respond far differently to a production of La Bobeme than will someone who has seen it five times."

Applying the assumption of a cultural hierarchy of quality evaluation in the arts (Bourdieu, 1993) to the field of theater reception, Boerner $e t$ al. (in press) expected differences between occasional and frequent theatergoers' expectation and perception of a performance, Due to their connoisseurship, frequent visitors know what is considered "good," resulting in certain standards and criteria sanctioned by their cultural field. Instead, occasional visitors apply the standards of popular appeal. Interviewing visitors of a Shakespeare performance at a professional German community theater, differences were found between occasional and frequent theatergoers concerning the relative importance of the antecedents of overall enjoyment in theater. Applying these results to the field of opera, we expect differences between occasional and frequent visitors regarding the relative importance of the antecedents of their satisfaction in opera.

\section{Hypothesis 2b. Occasional and frequent visitors differ regarding the relative importance of the individual antecedents of customer satisfaction in opera.}

\section{Metbods}

\section{Research methodology and design}

Since this study aims at testing hypotheses on customer satisfaction in opera, a deductive research approach is adopted. Accordingly, a self-administered survey was carried out in an opera house in order to collect visitors' experiences during their visit. Selfadministered surveys are considered to be cost efficient without reductions in data quality and standardization (Dillman, 2007). In addition, since interviewers are nearly entirely left out of the data collection process, respondents can take their time in responding to the items and give more thoughtful answers - thereby assuring sufficient data quality.

\section{Measures}

Since no validated instrument for the assessment of customer satisfaction in opera existed, we developed multi-item scales for all antecedents included in our model (see Figure 1), except for the perceived artistic quality. The latter was measured using the four-item scale developed and validated by Boerner et $a l$. (2008). The items for each construct are given in Table 1. Following recommendations in literature (Dillman, 2007), closed-ended questions with ordered response categories were used with 1 indicating the lowest ("strongly disagree") and 5 indicating the greatest quality 
Table 1. Questionnaire for customer satisfaction in opera: constructs and items

\begin{tabular}{|c|c|c|}
\hline $\begin{array}{l}\text { Construct } \\
\text { (number of items) }\end{array}$ & $\begin{array}{l}\text { Item } \\
\text { number }\end{array}$ & Items \\
\hline \multirow{5}{*}{$\begin{array}{l}\text { Customer satisfaction } \\
\text { in opera (5) }\end{array}$} & CS_1 & My expectations concerning the evening were met completely \\
\hline & CS_2 & All in all, the evening was an amazing experience for me \\
\hline & CS_3 & I an very disappointed with tonight ${ }^{R}$ \\
\hline & $\operatorname{cs} 4$ & This evening in the opera will leave a positive memory for a long time \\
\hline & CS_5 & Thanks to this evening, I resolved to attend the opera more often \\
\hline \multirow{4}{*}{$\begin{array}{l}\text { Perceived artistic } \\
\text { quality }(4)\end{array}$} & PAQ_1 & All in all, I was convinced by the artistic quality of the performance \\
\hline & PAQ_2 & In my opinion, this was an artistic top performance \\
\hline & PAQ_3 & $\begin{array}{l}\text { It would not be a loss, if this production was removed from } \\
\text { the playing schedule soon }{ }^{\mathrm{R}}\end{array}$ \\
\hline & PAQ_4 & $\begin{array}{l}\text { I would expect this performance to receive the highest praise } \\
\text { from the critics }\end{array}$ \\
\hline \multirow[t]{6}{*}{ Appraisal (6) } & A_1 & I enjoyed the performance and felt comfortable \\
\hline & A_2 & During the performance, I felt happy and relaxed \\
\hline & A_3 & During the performance, $I$ was in good spirits \\
\hline & A_ 4 & Time spun away during the performance \\
\hline & A 5 & During the performance, I was able to forget everything around ine \\
\hline & A_6 & During the performance, I was emotionally hooked \\
\hline \multirow{4}{*}{ Recall from memory (4) } & RM_l & The performance inspired positive memories \\
\hline & RM_2 & $\begin{array}{l}\text { Occasionally I was sad during the performance, because negative } \\
\text { memories were inspired }\end{array}$ \\
\hline & RM_3 & $\begin{array}{l}\text { The performance was able to bring experiences and events of } \\
\text { my own life to mind }\end{array}$ \\
\hline & RM_4 & $\begin{array}{l}\text { During the performance, I was reminded of the problems of } \\
\text { my everyday life from time to time }\end{array}$ \\
\hline \multirow{6}{*}{$\begin{array}{l}\text { Empathy/ } \\
\text { identification }(6)\end{array}$} & E/I_1 & For me, the behavior of Papageno and Papagena is exemplary \\
\hline & $\mathrm{E} / \mathrm{l} \_2$ & I could identify myself entirely with Papageno and Papagena \\
\hline & $\mathrm{E} / 1 \_3$ & $\begin{array}{l}\text { Papageno and Papagena stand for values which are very } \\
\text { important for me personally }\end{array}$ \\
\hline & $\mathrm{E} / \mathrm{I} 4$ & I was able to feel empathy with the performers \\
\hline & $\mathrm{E} / \mathrm{I} \_5$ & During the performance, I was thrilled by the performers' fate \\
\hline & E/I_6 & During the performance, 1 was able to feel for the performers \\
\hline \multirow{5}{*}{$\begin{array}{l}\text { Dimensions operating } \\
\text { during the performance (5) }\end{array}$} & DD__1 & The auditorium has very good acoustics \\
\hline & DD_2 & My seat was very comfortable \\
\hline & $D_{-3} 3$ & From my seat I had a very good view of the stage \\
\hline & DD_4 4 & $\begin{array}{l}\text { During the performance, annoying distractions (e.g., noises) } \\
\text { took place }^{\mathrm{R}}\end{array}$ \\
\hline & DD_5 & The auditorium's temperature was very pleasant \\
\hline \multirow{3}{*}{$\begin{array}{l}\text { Dimensions operating } \\
\text { before and after the } \\
\text { performance (3) }\end{array}$} & DBA_1 & $\begin{array}{l}\text { I was very pleased with the service of the house (hospitality, } \\
\text { cloak room, parking lots, etc.) }\end{array}$ \\
\hline & DBA_2 & $\begin{array}{l}\text { The location where the audience lingers before and after the } \\
\text { performance is pleasing and invites to stay }\end{array}$ \\
\hline & DBA_3 & This theatre's ambience is very pleasant \\
\hline
\end{tabular}

${ }^{\mathrm{R}}$ Polarity reversed.

Note: In order to present the statements as concrete as possible, some of the items were directly related to the performance of W.A. Mozart's The Magic Flute that was used for data collection.

("strongly agree"). Visitors' age was included as control variable.

\section{Procedure and sample}

In order to get insights into customer satisfaction of a "typical" opera audience, we selected
Dessau Opera House for data collection, which is famous for its conventional and conservative mainstream productions. Furthermore, with 1030 seats Dessau Opera House is one of Germany's largest opera houses, which should facilitate data collection. Randomly chosen visitors were asked to answer a questionnaire 
Table 2. Measures of global fit for the models estimated (confirmatory factor analyses)

\begin{tabular}{lrrrrrrrr}
\hline & $x^{2}$ & df & $p$ & $\chi^{2} / \mathrm{df}$ & NFI & TLI & CFI & RMSEA \\
\hline Model 1 & 1115.42 & 474 & 0.00 & 2.35 & 0.70 & 0.78 & 0.80 & 0.108 \\
Model 2 & 473.99 & 209 & 0.00 & 2.27 & 0.82 & 0.87 & 0.89 & 0.105 \\
\hline
\end{tabular}

NFI, normed fit index; TLI, Tucker-Lewis index; RMSEA, root mean square error of approximation.

after attending a live performance of The Magic Flute by W.A. Mozart. This piece was chosen for data collection since it has been the opera most often put on stage in Germany for quite some time now (Deutscher Buehnenverein, 2006).

After an announcement of the study had been made, the questionnaires were distributed among audience members. One hundred twenty questionnaires were completed resulting in a response rate of approximately $35 \%$. In comparison to similar surveys (Reuband, 2005) and considering time restrictions when collecting data in theaters and operas (Roose et al., 2003), this can be seen as an acceptable value. Of those 120 questionnaires, 4 (3.3\%) were excluded due to limited data quality (missing values $>10 \%$ in scale items), resulting in a final sample of 116 visitors. Since participants were predominantly female $(58 \%)$, in their middle ages (being 49 years of age on average; $S \mathrm{D}=16$, range $=18-75$ ), and preponderantly holding a university degree (66\%), our sample can be considered representative for the typical opera audience (Robinson, 1998; Neuhoff, 2001; National Endowment for the Arts, 2002).

\section{Data analysis}

For the 116 visitors in our sample, a maximum of $3(7.1 \%)$ missing values in the items of the scales was observed. Prior to the main data analyses, we therefore imputed these missing values by using the expectation-maximization (EM) algorithm. While being one of the recommended methods for preventing biases caused by not completely random missing data (Allison, 2001; Schafer and Graham, 2002), the EM algorithm estimates missing data using an iterative maximum-likelihood procedure (Zwingmann et al., 2006). The imputation was conducted with the software NORM (Graham et al., 2003).

In accordance with Kline (2005), confirmatory factor analyses (CFA) were run with AMOS 16.0 (Arbuckle and Wothke, 2003) in order to assess measurement validity. In Model 1, we included all 33 scale items as respective indicators of the underlying seven latent constructs (i.e., customer satisfaction, perceived artistic quality, level of appraisal, recall from memory, empathy/identification, perceived quality of dimensions operating during the performance, and perceived quality of dimensions operating before and after the performance). However, according to globalfit measures, this model showed only poor agreement with the empirical data (see Table 2). The $\chi^{2}$ value revealed significant differences between the empirical and the model-implied covariances. In addition, the fit index CFI as well as the incremental fit indices NFI and TLI fell below the threshold of 0.90 . Therefore, items with insufficient model compatibility were gradually eliminated from the model (a procedure conventionally termed "specification search," McCallum, 1986; see also Byrne, 2001; Hair et al., 2004).

The resulting model (Model 2) included 23 items and reached an acceptable global data fit (see Table 2). Moreover, measures of local fit demonstrated that each latent construct was reliably measured by the assigned items. All factor loadings were significant (see Table 3) and for every manifest item (except for two), more than $30 \%$ of its information was predicted by the underlying construct, that is, the indicator reliability exceeded 0.3 (see Table 3 ). Furthermore, both the factor reliabilities and the average proportions of indicator variance 
Table 3. Measures of local fit for model 2

\begin{tabular}{|c|c|c|c|c|c|}
\hline Factor & $\begin{array}{l}\text { Item } \\
\text { number }\end{array}$ & $\begin{array}{l}\text { Indicator } \\
\text { reliability }\end{array}$ & $\begin{array}{c}t-\text { Value of } \\
\text { factor loading }\end{array}$ & $\begin{array}{l}\text { Factor } \\
\text { reliability }\end{array}$ & $\begin{array}{c}\text { Average variance } \\
\text { extracted }\end{array}$ \\
\hline \multirow{6}{*}{$\begin{array}{l}\text { Thresholds for acceptable fit } \\
\text { Customer satisfaction }\end{array}$} & & $\geq 0.30$ & & \multirow{6}{*}{$\begin{array}{r}\geq 0.60 \\
0.94\end{array}$} & \multirow{6}{*}{$\begin{array}{r}\geq 0.50 \\
0.79\end{array}$} \\
\hline & & & & & \\
\hline & CS_1 & 0.92 & -a & & \\
\hline & $\operatorname{cs} 2$ & 0.94 & $26.29^{* * * *}$ & & \\
\hline & $\mathrm{CS}_{3} 3$ & 0.66 & $13.65^{* * *}$ & & \\
\hline & $\mathrm{CS}_{4} 4$ & 0.67 & $13.82^{* * *}$ & & \\
\hline \multirow[t]{4}{*}{ Perceived artistic quality } & & & & \multirow[t]{4}{*}{0.91} & \multirow{4}{*}{0.76} \\
\hline & PAQ_1 & 0.83 & $12.29^{* \ldots * k}$ & & \\
\hline & PAQ 2 & 0.81 & $11.99^{* * *}$ & & \\
\hline & PAQ 4 & 0.66 & - & & \\
\hline \multirow{4}{*}{$\begin{array}{l}\text { Dimensions operating } \\
\text { before and after the } \\
\text { performance }\end{array}$} & & & & \multirow[t]{4}{*}{0.76} & \multirow[t]{4}{*}{0.52} \\
\hline & DBA_1 & 0.34 & $5.49^{* * *}$ & & \\
\hline & DBA_2 & 0.81 & $6.41^{* * * *}$ & & \\
\hline & $D B A \_3$ & 0.44 & $-a$ & & \\
\hline \multirow{4}{*}{$\begin{array}{l}\text { Dimensions operating } \\
\text { during the performance }\end{array}$} & & & & \multirow[t]{4}{*}{0.62} & \multirow[t]{4}{*}{0.36} \\
\hline & $\mathrm{DD} \_1$ & 0.73 & $-^{a}$ & & \\
\hline & DD_2 & 0.21 & $4.04^{* * * \pi}$ & & \\
\hline & $\mathrm{DD}_{3} 3$ & 0.41 & $5.03^{* * *}$ & & \\
\hline \multirow{5}{*}{ Appraisal } & & & & \multirow[t]{5}{*}{0.93} & \multirow[t]{5}{*}{0.77} \\
\hline & A_1 & 0.80 & $-^{\mathbf{a}}$ & & \\
\hline & A_2 & 0.77 & $14.11^{* * *}$ & & \\
\hline & A_5 & 0.75 & $13.56^{* * *}$ & & \\
\hline & A_6 & 0.77 & $13.96^{* * *}$ & & \\
\hline \multirow{4}{*}{ Recall from memory } & & & & \multirow[t]{4}{*}{0.68} & \multirow[t]{4}{*}{0.43} \\
\hline & RM_1 & 0.67 & $-;$ & & \\
\hline & RM_3 & 0.40 & $7.14^{* * *}$ & & \\
\hline & RM_4 & 0.17 & $4.33^{* * * *}$ & & \\
\hline \multirow{4}{*}{ Empathy/identification } & & & & \multirow{4}{*}{0.92} & \multirow{4}{*}{0.79} \\
\hline & $\mathrm{E} / \mathrm{I} \_4$ & 0.76 & $-{ }^{a}$ & & \\
\hline & E/I_5 & 0.74 & $12.67^{* * *}$ & & \\
\hline & E/1_6 & 0.87 & $14.83^{* * *}$ & & \\
\hline
\end{tabular}

Note: For thresholds of acceptable fit, see Bagozzi and Baumgartner (1994) and Hair et al. (2004).

"Linstandardized values were set to equal 1 in order to ensure identifiability. ${ }^{* * *} p \leq 0.001 .{ }^{* *} p \leq 0.010 . * 0 \leq 0.050$.

extracted by the corresponding latent construct went beyond the critical values (see Table 3). Only the constructs "dimensions operating during the performance" and "recall from memory" failed to reach the critical value for the average proportions of indicator variance - even though not substantially.

\section{Results}

\section{Descriptive statistics}

Descriptive statistics for all seven scales are shown in Table 4 . Although the mean scores for the scales exceeded the midpoint of the theoretical range substantially (exception: "recall from memory"), all items exhibit the full range of response and adequate variation with good distributional properties.

\section{Antecedents of customer satisfaction in opera}

In a linear multiple regression analysis, customer satisfaction in opera was regressed on the antecedents included in Figure 1, controlling for visitors' age. As can be seen in Table 5 , 
Table 4. Descriptive statistics and correlations $(n=116)$

\begin{tabular}{|c|c|c|c|c|c|c|c|c|}
\hline Scale & $M$ & $\mathrm{SD}$ & $\mathrm{CS}$ & PAQ & $\mathrm{DBA}$ & $\mathrm{DD}$ & A & $\mathrm{RM}$ \\
\hline CS & 4.20 & 0.99 & & & & & & \\
\hline PAQ & 3.84 & 1.02 & $0.88^{* *}$ & & & & & \\
\hline DBA & 4.41 & 0.59 & 0.10 & $0.19^{*}$ & & & & \\
\hline DD & 4.38 & 0.64 & 0.10 & 0.15 & $0.35^{* *}$ & & & \\
\hline A & 3.91 & 0.98 & $0.87^{* *}$ & $0.86^{* *}$ & 0.15 & 0.12 & & \\
\hline $\mathrm{RM}$ & 2.86 & 0.91 & $0.39^{* * *}$ & $0.48^{* 3}$ & $0.34^{* *}$ & $0.21^{*}$ & $0.54^{* *}$ & \\
\hline $\mathrm{E} / \mathrm{l}$ & 3.71 & 1.04 & $0.73^{* * *}$ & $0.77^{* *}$ & $0.34^{* *}$ & $0.21^{*}$ & $0.74^{* *}$ & $0.69^{* * *}$ \\
\hline
\end{tabular}

$\mathrm{CS}$, customer satisfaction; $\mathrm{PAQ}$, perceived artistic quality; $\mathrm{DBA}$, dimensions operating before and after the performance; $\mathrm{DD}$, dimensions operating during the performance; $\mathrm{A}$, appraisal; RM, recall from memory; $\mathrm{E} / \mathrm{I}$, empathy/ identification.

$p \leq 0.001{ }^{* * *} p \leq 0.010 .{ }^{*} p \leq 0.050$.

customer satisfaction in opera was significantly predicted by appraisal $(\beta=0.48, p \leq 0.001)$, their perception of the artistic performance quality $(\beta=0.40, p \leq 0.001)$, empathy/identification $(\beta=0.21, p \leq 0.01)$, and recall from memory $(\beta=-0.20, \quad p \leq 0.001)$ (adjusted $R^{2}=.83$ ). Age did not turn out as significant control variable.

Interestingly, recall from memory had a negative $\beta$-coefficient, that is, the more the action on stage reminded a visitor of his/ her own life the lower was his/her satisfaction. However, customers' perception of the peripheral service quality, that is, dimensions operating during the performance and dimensions operating before and after the performance, failed to reach significance as predictors for customer satisfaction in opera. Hypothesis 1 was thus only partially confirmed.

\section{Differences in customer satisfaction in opera within the audience}

In order to identify differences between audience segments with regard to the relative importance visitors give to the individual antecedents of their satisfaction (Hypotheses $2 a$ and $2 b$ ), interaction terms were added to the regression analysis testing Hypothesis 1.

Including interaction terms between the antecedents of customer satisfaction and gender, only the interaction between appraisal and gender $(\beta=-0.08, p \leq 0.05)$ reached

Table 5. Summary of regression analysis for variables predicting customer satisfaction in opera $(n=116)$

\begin{tabular}{|c|c|c|c|c|}
\hline Scale & $B$ & $\mathrm{SEB}$ & $\beta$ & $p$-Value \\
\hline \multicolumn{5}{|l|}{ Control } \\
\hline Age & & & & 0.454 \\
\hline \multicolumn{5}{|l|}{ Antecedents } \\
\hline Appraisal & 0.48 & 0.08 & $0.48^{* i n *}$ & 0.000 \\
\hline Perceived artistic quality & 0.38 & 0.08 & $0.40^{* * *}$ & 0.000 \\
\hline Empathy/identification & 0.20 & 0.07 & $0.21^{* *}$ & 0.005 \\
\hline Recall from memory & -0.21 & 0.06 & $-0.20^{* * *}$ & 0.000 \\
\hline Dimensions operating during the performance & & & & 0.659 \\
\hline Dimensions operating before and after the performance & & & & 0.186 \\
\hline$R^{2}$ & 0.84 & & & \\
\hline Adjusted $R^{2}$ & 0.83 & & & \\
\hline$F$ & $142.03^{* * *}$ & & & \\
\hline
\end{tabular}

${ }^{* * *} p \leq 0.001 . * * p \leq 0.01$. 
Table 6. Summary of regression analysis for variables predicting customer satisfaction in opera (including interaction terms between the antecedents and visitors' gender; $n=116$ )

\begin{tabular}{|c|c|c|c|c|}
\hline Scale & B & SE B & $\beta$ & $p$-Value \\
\hline \multicolumn{5}{|l|}{ Antecedents } \\
\hline Appraisal & 0.45 & 0.08 & $0.45^{* * *}$ & 0.000 \\
\hline Perceived artistic quality & 0.40 & 0.08 & $0.41^{* * *}$ & 0.000 \\
\hline Empathy/identification & 0.23 & 0.07 & $0.24^{* * *}$ & 0.001 \\
\hline Recall from memory & -0.24 & 0.06 & $-0.22^{* * * *}$ & 0.000 \\
\hline Dimensions operating during the performance & & & & 0.594 \\
\hline Dimensions operating before and after the performance & & & & 0.246 \\
\hline Gender & -0.17 & 0.08 & $-0.09^{*}$ & 0.029 \\
\hline \multicolumn{5}{|l|}{ Interaction terms } \\
\hline Appraisal $\times$ gender & -0.16 & 0.08 & $-0.08^{*}$ & 0.036 \\
\hline Perceived artistic quality $\times$ gender & & & & 0.502 \\
\hline Empathy/identification $\times$ gender & & & & 0.124 \\
\hline Recall from memory $\times$ gender & & & & 0.148 \\
\hline Dimensions operating during the performance $\times$ gender & & & & 0.702 \\
\hline Dimensions operating before and after the performance $\times$ gender & & & & 0.630 \\
\hline$R^{2}$ & 0.85 & & & \\
\hline Adjusted $R^{2}$ & 0.84 & & & \\
\hline$F$ & $102.14^{* * * *}$ & & & \\
\hline
\end{tabular}

${ }^{* * * *} p \leq 0.001{ }^{*} p \leq 0.05$

significance (see Table 6). Since women $(n=67)$ differed from men $(n=49)$ in the relative importance that is given to appraisal, Hypothesis $2 a$ was partly confirmed.
Next, Hypothesis $2 b$, assuming differences between occasional (i.e., attending the opera three times during a year on average or less; $n=59$ ) and frequent (i.e., attending the opera

Table 7. Summary of regression analysis for variables predicting customer satisfaction in opera (including interaction terms between the antecedents and visitors' attendance frequency; $n=116$ )

\begin{tabular}{|c|c|c|c|c|}
\hline Scale & $\mathbf{B}$ & $\mathrm{SE} \mathrm{B}$ & $\beta$ & $p$-Value \\
\hline \multicolumn{5}{|l|}{ Antecedents } \\
\hline Appraisal & 0.48 & 0.08 & $0.48^{* * *}$ & 0.000 \\
\hline Perceived artistic quality & 0.38 & 0.08 & $0.40^{* * *}$ & 0.000 \\
\hline Empathy/identification & 0.20 & 0.07 & $0.21^{* ; *}$ & 0.005 \\
\hline Recall from memory & -0.21 & 0.06 & $-0.20^{* * *}$ & 0.000 \\
\hline Dimensions operating during the performance & & & & 0.659 \\
\hline Dimensions operating before and after the performance & & & & 0.186 \\
\hline Attendance frequency & & & & 0.383 \\
\hline \multicolumn{5}{|l|}{ Interaction terms } \\
\hline Appraisal $\times$ attendance frequency & & & & 0.421 \\
\hline Perceived artistic quality $\times$ attendance frequency & & & & 0.534 \\
\hline Empathy/identification $\times$ attendance frequency & & & & 0.453 \\
\hline Recall from memory $\times$ attendance frequency & & & & 0.290 \\
\hline Dimensions operating during the & & & & 0.283 \\
\hline \multicolumn{5}{|l|}{ performance $x$ attendance frequency } \\
\hline Dimensions operating before and after the & & & & 0.733 \\
\hline performance $\times$ attendance frequency & & & & \\
\hline$R^{2}$ & 0.84 & & & \\
\hline Adjusted $R^{2}$ & 0.83 & & & \\
\hline$F$ & $142.03^{* * *}$ & & & \\
\hline
\end{tabular}


Table 8. Summary of regression analysis for variables predicting customer satisfaction in opera separated by gender (women: $n=67$; men: $n=49$ )

\begin{tabular}{|c|c|c|c|c|}
\hline \multirow[t]{2}{*}{ Scale } & \multicolumn{2}{|c|}{ Women } & \multicolumn{2}{|c|}{ Men } \\
\hline & $\beta$ & $p$-Value & $\beta$ & $p$-Value \\
\hline Appraisal & $0.31^{*}$ & 0.011 & $0.62^{* * * *}$ & 0.000 \\
\hline Perceived artistic quality & $0.61^{* * *}$ & 0.000 & $0.45^{* * *}$ & 0.000 \\
\hline Empathy/identification & & 0.073 & & 0.166 \\
\hline Recall from memory & & 0.442 & $-0.20^{* *}$ & 0.004 \\
\hline Dimensions operating during the performance & & 0.887 & & 0.532 \\
\hline Dimensions operating before and after the performance & & 0.662 & & 0.272 \\
\hline$R^{2}$ & 0.80 & & 0.87 & \\
\hline Adjusted $R^{2}$ & 0.79 & & 0.86 & \\
\hline$F$ & $127.42^{* * * *}$ & & $100.09^{* * * *}$ & \\
\hline
\end{tabular}

more than three times during a year; $n=57$ ) theatergoers, was tested. Calculating another regression analysis, none of the interaction terms between the antecedents of customer satisfaction and attendance frequency obtained significance (see Table 7). Consequently, Hypothesis 2b was rejected.

Since this is the first published study on differences between audience segments concerning the antecedents of customer satisfaction in opera, we further searched for possible differences in an exploratory approach. Separate regression models conducted for the audience segments under study revealed the following tendencies: While women's satisfaction was determined by their perception of the artistic quality $(\beta=0.61, \quad p \leq 0.001 ;$ see Table 8) and their level of appraisal $(\beta=0.31, p \leq 0.05)$, men's satisfaction was determined by the same variables, yet in different order (appraisal: $\beta=0.62$, $p \leq 0.001$; perceived artistic quality: $\beta=0.45$, $p \leq 0.001$ ). Contrary to the female sample, recall from memory was another significant antecedent $(\beta=-0.20, p \leq 0.01)$ in the male sample.

For both occasional visitors and frequent visitors the perceived artistic quality was the

Table 9. Summary of regression analysis for variables predicting customer satisfaction in opera separated by attendance frequency (occasional visitors: $n=59$, frequent visitors: $n=57$ )

\begin{tabular}{|c|c|c|c|c|}
\hline \multirow[t]{2}{*}{ Scale } & \multicolumn{2}{|c|}{ Occasional visitors } & \multicolumn{2}{|c|}{ Frequent visitors } \\
\hline & $\beta$ & $p$-Value & $\beta$ & $p$-Value \\
\hline Appraisal & $0.42^{* *}$ & 0.002 & $0.45^{* * *}$ & 0.000 \\
\hline Perceived artistic quality & $0.43^{* *}$ & 0.001 & $0.50^{* * * *}$ & 0.000 \\
\hline Empathy/identification & $0.26^{*}$ & 0.016 & & 0.355 \\
\hline Recall from memory & $-0.30^{* *}$ & 0.001 & & 0.182 \\
\hline Dimensions operating during the performance & & 0.889 & & 0.671 \\
\hline Dimensions operating before and after the performance & & 0.343 & & 0.605 \\
\hline$R^{2}$ & 0.81 & & 0.84 & \\
\hline Adjusted $R^{2}$ & 0.80 & & 0.84 & \\
\hline$F$ & $58.79^{* * *}$ & & $143.05^{* * *}$ & \\
\hline
\end{tabular}

${ }^{* * * *} p \leq 0.001{ }^{* *} p \leq 0.01{ }^{*} p \leq 0.05$ 
main antecedent of their satisfaction in opera (occasional visitors: $\beta=0.43, p \leq 0.001$; frequent visitors: $\beta=0.50, \quad p \leq 0.001$; see Table 9). However, while occasional visitors additionally took their level of appraisal $(\beta=0.42, p \leq 0.01)$, recall from memory $(\beta=-0.30, p \leq 0.001)$, and empathy/identification $(\beta=0.26, p \leq 0.05)$ into account, in the sample of frequent visitors only the level of appraisal reached significance $(\beta=0.45$, $p \leq 0.001)$.

\section{Discussion}

Motivated by the call for an intensified customer orientation in performing arts organizations (Gainer and Padanyi, 2002; Rentschler et al., 2002; Kotler and Scheff, 2007) on the one hand and the lack of research on visitor satisfaction in opera on the other hand, the aim of our paper was to investigate customer satisfaction in opera. The results of our study contribute to answer two questions: (1) What are the antecedents of customer satisfaction in opera? (2) Are there differences within the audience regarding the relative importance that is given to the antecedents of customer satisfaction in opera?

\section{Antecedents of customer satisfaction in opera}

Reviewing literature in services marketing, music perception, and theater studies an integrative model of customer satisfaction in opera was developed, stating customer satisfaction to consist of (1) customers' cognitive perception of the core service, that is, the perceived artistic performance quality, (2) customers' emotional response to the core service, that is, the performance on stage segmented into level of appraisal, recall from memory, and level of empathy/identification, and (3) the perceived quality of the peripheral service - segmented into dimensions operating during the performance and dimensions operating before and after the performance. A field study in a public German opera company revealed the following findings: Visitors' level of appraisal turned out to be the main antecedent of customer satisfaction in opera, followed by the perceived artistic quality. Additionally, customer satisfaction in opera was significantly predicted by customers' level of empathy/identification and their recall from memory. The identified antecedents explain a considerable amount of variance $\left(R^{2}=0.83\right.$; see Table 5$)$ of visitors' satisfaction in opera. These findings confirm results found in the context of experiential marketing (Schmitt, 1999) and theater performances (Boerner et al., in press; Eversmann, 2004). Further, they reinforce the importance of emotions in the perception of opera performances (Scherer, 1995).

Interestingly, "recall from memory" had a negative coefficient, that is, the more the action on stage reminded a visitor of his/her own life the lower was his/her satisfaction. While we originally assumed this construct to be a positive determinant of visitors' satisfaction in opera, this result gives rise to the idea that its impact on visitors' satisfaction may be both positive and negative. The construct "recall from memory" means that the visitor is reminded of personal experiences while watching the presented performance. (Note that one example item was "The performance was able to bring experiences and events of my own life to mind.") This antecedent does not necessarily have to be a positive determinant. Rather, the effect of the individual recall from memory on a visitor's satisfaction is likely to depend on the quality of the recalled experience. If the visitor is reminded of a problematic or traumatic experience or episode of his/her life, he/she may leave the opera house less satisfied than otherwise. The overall impact of recall from memory on a visitor's satisfaction will thus result from the balance between positive recalls and negative recalls. The plot of The Magic Flute seems to have evoked more negative than positive recalls in the audience.

Surprisingly, customers' perception of the peripheral service quality - subdivided into dimensions operating during the performance and dimensions operating before and after - 
did not turn out to be an antecedent of their satisfaction in opera. This finding is contrary to both results from services marketing literature (e.g., McDougall and Levesque, 2000; Butcher, 2005) and marketing studies in the theater context which show a direct link from dimensions of the peripheral service to customer satisfaction (Garbarino and Johnson, 1999; Voss and Cova, 2006).

\section{Differences in customer satisfaction in opera within the audience}

Since the sources of customer satisfaction may vary from person to person - depending on individuals' personal and social characteristics (Hawes, 1979) - differences in the relative importance that is given to the individual antecedents were hypothesized. Thus, we expected our integrative model depicted in Figure 1 to differ according to the customer segment under study. Interpreting interaction terms, significant differences between men and women with regard to their level of appraisal were found. Conducting separate regression analyses for men and women, appraisal turned out to be a stronger antecedent for men's than for women's satisfaction in opera.

In addition, the separate regression analyses were used to discover further potential differences between the customer segments under study. In this exploratory effort, the following tendencies were revealed. First, the negative impact of "recall from memory" was only confirmed in the men's sample. In part, this result might be explained by the plot of The Magic Flute Papageno, one of the most prominent characters, has to pass several competitions before being able to free Pamina from the power of Sarastro. In our study, in particular male visitors may thus have been reminded of rather problematic experiences. However, given the limitations of our study (see below), this interpretation is highly speculative.

Second, similarities and differences were found between occasional and frequent visi- tors concerning the relative importance of the individual antecedents of their satisfaction. The perceived artistic quality is the main antecedent in both groups. This finding is only partially consistent with previous results stating that experienced visitors perceive a theater performance more analytically, whereas less experienced visitors perceive it more emotionally (Hargreaves and Colman, 1981; Harrer and Allesch, 1982; Bourgeon cp. Kotler and Scheff, 2007; Boerner et al., in press). However, the finding that empathy/ identification and recall from memory are predictors for occasional visitors only seems to confirm the idea of the more naive layman compared to the professional experienced visitor.

In sum, visitors' gender in part influenced the weighting of antecedents of customer satisfaction. Attendance frequency, in contrast, did not cause significant differences within the audience regarding the weighting of the antecedents of customer satisfaction in opera. Thus, according to our data, the model of customer satisfaction in opera developed in this paper seems only in part to be susceptible to influences from the audience segment under study.

\section{Limitations and avenues for further research}

Several limitations of the present study are worth mentioning. First, since we were not able to hark back to established measures, scales for measuring customer satisfaction in opera and its antecedents had to be developed for the purpose of this study. As these measures have not been validated in a separate sample, the results of this study have to be interpreted very carefully. However, the first application in the field achieved sufficient validity for all scales except for "recall from memory" and "dimensions operating during the performance." Further research on customer satisfaction in opera may thus use our questionnaire as a starting point. Second, as only the visitors of one performance in one opera house have been investigated, our 
results cannot be generalized to customer satisfaction in opera. Hence, to allow for sound conclusions and recommendations, additional field studies in the opera are required in order to obtain more data. Such studies would have to control, for example, for the genre of the presented work (e.g., "opera seria" or "opera buffa"), the type of performance (e.g., matinee, première, regular performance), the style of production (conventional versus modern or avant-garde), and the reputation of the opera company under study. Third, our sample was self-selected in that only volunteers completed the questionnaire, which may have resulted in a self-selection bias (Roose et al., 2003). However, given time restrictions for data collection in opera and the restricted willingness to participate in a study late at night, this limitation can hardly be avoided.

\section{Implications for marketing in opera companies}

Research in services marketing has shown that customer satisfaction is an antecedent of both customers' behavioral intentions and actual behavior outcomes. Looking at the antecedents of customer satisfaction in opera seems thus worthwhile. Hence, the results of our study may help marketing managers of professional opera companies to better understand their customers. Given these results, some practical implications can be formulated.

Probably the most interesting contribution of our study is the finding that customers' perception of the peripheral service quality is of no importance for their satisfaction. If this holds true in further studies, efforts in opera marketing concentrating on the peripheral service quality will not help to achieve opera companies' performance objectives. In order to develop their audiences and counter negative tendencies such as shrinking audience sizes and increased competition, opera companies' marketing efforts will have to focus on the core service, that is, the artistic performance on stage. Instead of emphasizing conflicts between art/creativity on one side and business/management on the other, opera companies may want to align their artistic mission with customers' needs and wants in order to achieve performance objectives.

Since appraisal contributed considerably to customer satisfaction in our sample, focusing on both customers' cognitive and emotional responses to the stage performance turns out to be one promising possibility in audience development. Reducing customer satisfaction to a logical, rational evaluation of an evening in opera will fail to reach opera companies' performance objectives. Since it is mainly visitors' emotional response that makes for customer satisfaction in opera, a second major contribution of the present study to opera management is that professional opera companies may attract broader audiences if they aim at making an evening in opera a source of emotional experiences for their customers.

Comparing the relative importance which members of different audience segments assign to the individual antecedents of their satisfaction, our study revealed only minor and mostly insignificant differences between women and men, and between occasional and frequent visitors. As a third contribution of the present study, our results thus suggest that neither gender nor attendance frequency are appropriate and purposeful segmentation variables in the present context. However, since segment marketing offers several benefits over mass marketing (e.g., Kotler, 1997), research on customer satisfaction in opera should explore alternative criteria for segmentation, including non-demographic variables such as lifestyle, personality, and goals of arts attendance (Kotler and Scheff, 2007). If criteria for segmentation will be identified, opera companies could benefit from splitting the audience into various segments. Thus, they would be able to evaluate various segments taking into account both the attractiveness of the segment and the companies' goals and objectives. Following this evaluation phase, the opera company would then have to decide which and how many segments to target. 


\section{Biograpbical notes}

Jobanna Jobst is a research associate in the Department of Politics and Management at the University of Konstanz, Germany. Her main research interests lie in the field of strategic management of cultural organizations.

Dr. Sabine Boerner is Professor in Management, especially Strategy and Leadership at the University of Konstanz, Germany. Her research interests centre on organizational behaviour and management, including leadership studies, organizational innovation, strategic management, and the management of cultural industries. She has published a variety of books and journal articles on organizational behaviour and management.

\section{References}

Allison PD. 2001. Missing Data. Sage: Thousand Oaks.

Anderson E, Sullivan M. 1993. The antecedents and consequences of customer satisfaction for firms. Marketing Science 12(2): 125-143.

Anderson S, Klein Pearo L, Widener S. 2008. Drivers of service satisfaction. Linking customer satisfaction to the service concept and customer characteristics. Journal of Service Research 10(4): 365-381.

Arbuckle JL, Wothke W. 2003. AMOS 4.0 User's Guide. Small-Waters Corporation: Chicago.

Auvinen T. 2001. Why is it difficult to manage an opera house? The artistic-economic dichotomy and its manifestations in the organizational structures of five opera organizations. Journal of Arts Management, Lau, and Society 30(4): 268-282.

Bagozzi RP, Baumgartner H. 1994. The evaluation of structural equation models and hypothesis testing. In Principles of Marketing Research, Bagozzi R (ed.). Blackwell Publishers: Cambridge; $386-422$.

Bitner MJ. 1990. Evaluating service encounters: the effects of physical surroundings and employee responses. Journal of Marketing 54: 69-82.

Boerner S. 2002. Fuhrungsverbalten und Fibrungserfolg. Beitrag zu einer Theorie der Fübrung am Beispiel des Musiktheaters. Deutscher Universitaetsverlag: Wiesbaden.

Boerner S. 2004. Artistic quality in an opera company - towards the development of a concept.
Nonprofit Management and Leadership 4(4): 425-436.

Boerner S, Jobst J. 2008. The perception of artistic quality in opera. Results from a field study. Journal of New Music Research 37(3): 233-245.

Boerner S, Neuhoff H, Renz S, Moser V. 2008. Evaluation in music theater: empirical results on content and structure of the audience's quality judgment. Empirical Studies of the Arts 26(1): 15-35.

Boerner S, Moser V, Jobst J. In press. Evaluating cultural industries: investigating visitors' satisfaction in theater. Service Industries Journal 31: 7.

Boorsma M. 2006. A strategic logic for arts marketing. Integrating customer value and artistic objectives. International Journal of Cultural Policy 12(1): 73-92.

Bouder-Pailler D. 1999. A model for measuring the goals of theatre attendance. International Jour nal of Arts Management 1(2): 4-15.

Bourdieu P. 1993. The Field of Cultural Production. Columbia University Press: New York.

Butcher K. 2005. Differential impact of social influence in the hospitality encounter. International Joumal of Contemporary Hospitality Management 17(2): 125-135.

Butcher K, Sparks B, O'Callaghan F. 2003. Beyond core service. Psychology E Marketing 20(3): 187208.

Byrne B. 2001. Structural Equation Modeling With AMOS. Basic Concepts, Applications, and Programming. Lawrence Erlbaum: Mahwah.

Caust J. 2003. Putting the 'art' back into arts policy making: how arts policy has been 'captured' by the economists and marketers. International Joumal of Cultural Policy 9(1): 51-63.

Chase R, Stewart D. 1994. Make your service failsafe. Sloan Management Review 35(3): 35-44.

Colbert F, Nantel J, Bilodeau S, Rich JD. 2001. Marketing Culture and the Arts. Presses HEC: Montreal.

Cooil B, Keiningham T, Aksoy L, Hu M. 2007. A longitudinal analysis of customer satisfaction and share of wallet: investigating the moderating effect of customer characteristics. Joumal of Marketing 71: 67-83.

Cooper-Martin E. 1991. Consumers and movies: some findings on experiential products. Advances in Consumer Research 18: 372-378.

Cronin JJ, Taylor SA. 1992. Measuring service quality: a reexamination and extension. Joumal of Marketing 56: 55-68. 
Cronin JJ, Brady M, Hult G. 2000. Assessing the effects of quality, value, and customer satisfaction on consumer behavioral intentions in service environments. Journal of Retailing 76: 193-218.

Cuadrado M, Molla A. 2000. Grouping performing arts consumers according to attendance goals. International Journal of Arts Management 2(3): 54-60.

Dabholkar P. 1995. A contingency framework for predicting causality between customer satisfaction and service quality. In Advances in Consumer Research, Kardes F, Sujan M (eds). Association for Consumer Research: Provo; 101-108.

Dabholkar P, Shepherd CD, Thorpe DI. 2000. A comprehensive framework for service quality: an investigation of critical conceptual and measurement issues through a longitudinal study. Journal of Retailing 76(2): 139-173.

Deutscher Buehnenverein. 2006. Wer spielte was? Werkstatistik 2004/05 des Deutschen Buebnenvereins. Mykenae Verlag: Darmstadt.

Dillman D, 2007. Mail and Internet surveys. The tailored design method. Wiley: Hoboken.

DiMaggio P. 1987. Nonprofit organizations in the production and distribution of culture. In The Nonprofit Sector. A Research Handbook, Powell W (ed.). Yale University Press: New Haven and London; 195-220.

DiMaggio P, Useem M, Brown P. 1978. Audience Studies of the Performing Arts and Museums: A Critical Review. National Endowment for the Arts: Washington.

Eikhof DR, Haunschild A. 2007. For art's sake! Artistic and economic logics in creative production. Journal of Organizational Bebavior 28: $523-538$.

Eversmann $P G .2004$. The experience of the theatrical event. In Theatrical Events. BordersDynamics-Frames, Cremona VA, Eversmann $P$, van Maanen $H$, Sauter W, Tulloch J (eds). Rodopi: Amsterdam; 139-174.

Gainer B, Padanyi P. 2002. Applying the marketing concept to cultural organisations: an empirical study of the relationship between market orientation and performance. International Journal of Nonprofit and Voluntary Sector Marketing $7(2): 182-193$.

Garbarino E, Johnson MS. 1999. The different roles of satisfaction, trust, and commitment in customer relationships. Journal of Marketing 63: $70-87$.

Graham JW, Cumsille PE, Elek-Fisk E. 2003. Methods for handling missing data. In Research Methods in Psychology, Schinka JA, Velicer WF (eds). Wiley: New York; 87-114.

Groenroos C. 1984 . A service quality model and its marketing implications. European Journal of Marketing 18(4): 36-44.

Guenter B. 2001. Kulturmarketing. In Brancbenspezifisches Marketing. Grundlagen, Besonderbeiten, Gemeinsamkeiten, T'scheulin DK, Helmig B (eds). Wiesbaden: Gabler; 331-349.

Gustafsson A, Johnson M, Roos I. 2005. The effects of customer satisfaction, relationship commitment dimensions, and triggers on customer retention. Journal of Marketing 69: 210-218.

Haefs S, Schmidt K. 1999. Wirkungsvolle Strukturen im Kulturbereich. Ergebnisse des Servicetests an 15 deutschen Theatern. Verlag Bertelsmann Stiftung: Gütersloh.

Hair JF, Anderson RE, Tatham RL, Black WC. 2004. Multivariate Data Analysis. Prentice-Hall: Upper Saddle River.

Hargreaves D, Colman A, 1981. The dimensions of aesthetic reactions to music. Psycbology of Music 9: 15-20.

Harrer G, Allesch C. 1982. Grundlagen der Musiktherapie und Musikpsychologie. Fischer: Stuttgart.

Hausmann A. 2007. Das Publikum von morgen. Herausforderungen des demographischen Wandels für Kulturbetriebe. Kulturpolitische Mitteilungen 117(2): 54-57.

Hawes DK. 1979. Satisfactions derived from leisure-time pursuits: an exploratory nationwide survey. Journal of Leisure Research 10(4): 247-264.

Henning-Thurau T, Gwinner K, Gremler D. 2002. Understanding relationship marketing outcomes. Journal of Service Research 4: 230-247.

Hill L, O'Sullivan C, O'Sullivan T. 2004. Creative Arts Marketing. Elsevier: Amsterdam.

Hirschman E, Holbrook M. 1982. Hedonic consumption: emerging concepts, methods and propositions. Journal of Marketing 46: 92-101. Hume M, Mort GS, Liesch PW, Winzar H. 2006. Understanding service experience in non-profit performing arts: implications for operations and service management. Journal of Operations Management 24: 304-324. 
Iacobucci D, Ostrom A. 1993. Gender differences in the impact of core and relational aspects of services on the evaluation of service encounters. Journal of Consumer Psychology 2(3): 257-286.

Iacobucci D, Grayson K, Ostrom A. 1994. The calculus of service quality and customer satisfaction: theoretical and empirical differentiation and integration. In Advances in Services Marketing and Management, Swartz T, Bowen D, Brown S (eds). JAI Press: Greenwich; 1-67.

Juslin P, Sloboda J. 2001. Music and Emotion. Oxford University Press: Oxford.

Kawashima N. 2000. Beyond the division of attenders and non-attenders. a study into audience development in policy and practice. In Research Paper No. 6, Bennett O (ed.). Centre for Cultural Policy Studies, University of Warwick: Coventry.

Kline RB. 2005. Principles and Practice of Structural Equation Modelling. Guilford Press: New York.

Koebner T. 1993. Handlungen mit Musik. Die Oper als Zeitspiegel, Leidenschaftsdrama, Gesamtkunstwerk. Mueller-Speiser: Salzburg.

Konijn EA. 1999. Spotlight on spectators: emotions in the theater. Discourse Processes 28(2): 169-194.

Kotler P. 1997. Marketing Management. Analysis, Planning, Implementation, and Control. Prentice-Hall: Upper Saddle River.

Kotler N, Kotler P. 1998. Museum Strategy and Marketing: Designing Missions, Building Audiences, Generating Revenue and Resources. Jossey Bass: San Francisco.

Kotler P, Scheff J. 2007. Standing Room Only. Strategies for Marketing the Performing Arts. Harvard Business School Press: Boston.

LaBarbera PA, Mazursky D. 1983. A longitudinal assessment of consumer satisfaction/dissatisfaction: the dynamic aspect of the cognitive process. Journal of Marketing Researcb 20: 393404 .

Lewis R, Booms B. 1983. The marketing aspects of service quality. In Emerging Perspectives on Services Marketing, Berry L, Shostack G, Upah $G$ (eds). American Marketing Association: Chicago; 99-107.

McCallum R. 1986. Specification searches in covariance structure modeling. $P$ sycbological Bulletin 100(1): 107-120.

McCarthy K, Brooks A, Lowell J, Zakaras L. 2001. The Performing Arts in a New Era. Rand: Santa Monica.
McDougall G, Levesque T. 2000. Customer satisfaction with services: putting perceived value into the equation. Journal of Services Marketing 14(5): 392-405

Meyers-Levy J, Sternthal B. 1991. Gender cues in the use of message differences and judgments. Journal of Marketing Research 28(1): 84-96.

Mittal V, Kumar P, Tsiros M. 1999. Attribute-level performance, satisfaction, and behavioral intentions over time: a consumption-system approach. Journal of Marketing 63: 88-101.

National Endowment for the Arts. 2002. Survey of Public Participation in the Arts. National Endowment for the Arts: Washington.

Neuhoff H. 2001. Die Altersstruktur von Konzertpublika. Querschnitte und Längsschnitte von Klassik und Pop in kultursoziologischer Analyse. In Musikforum 95, Deutscher Musikrat (ed.) Baerenreiter, Bosse: Kassel; 64-83.

Oliver R. 1980. A cognitive model of the antecedents and consequences of satisfaction decisions. Journal of Marketing Researcb 17: 460-469.

Oliver R. 1993. A conceptual model of service quality and service satisfaction: compatible goals, different concepts. In Advances in Services Marketing and Management, Swartz T, Bowen D, Brown S (eds). JAI Press: Greenwich; 65-85.

Oliver R. 1996. Satisfaction: A Behavioral Perspective on the Consumer. McGraw Hill: New York.

Oliver R, DeSarbo W. 1988. Response determinants in satisfaction judgments. Joumal of Consumer Research 14: 495-507.

Parasuraman A, Zeithaml V, Berry L. 1988. SERVQ UAL: a multiple-item scale for measuring consumer perceptions of service quality. Joumal of Retailing 64: 12-40.

Rentschler R, Radbourne J, Carr R, Rickard J. 2002. Relationship marketing, audience retention and performing arts organizations viability. Inter. national Journal of Nonprofit and Voluntary Sector Marketing 7(2): 118-130.

Reuband K. 2005. Sterben die Opernbesucher aus? Eine Untersuchung zur sozialen Zusammensetzung des Opernpublikums im Zeitvergleich. In Deutsches Jabrbuch für Kulturmanagement, Klein A, Knubben T (eds). Baden-Baden: Nomos; 123-138.

Robinson J. 1998. Take me out to the opera. American Demographics 20: 46-47. 
Roose H, Waege H, Agneessens F. 2003. Respondent related correlates of response behaviour in audience research. Quality \& Quantity 37: 411434.

Sargeant A. 1997. Marketing the arts. Classification of U.K. Theatre audiences. Journal of Nonprofit E Public Sector Marketing 5: 45-62.

Schafer JL, Graham JW. 2002. Missing data: our view of the state of the art. Psycbological Methods 7: 147-177.

Scheff J, Kotler P. 1996. Crisis in the arts: the marketing response. California Management Review 39(1): 28-52.

Scherer K. 1995. Expression of emotion in voice and music. Joumal of Voice 9(3): 235248.

Scherer K. 2004. Which emotions can be induced by music? What are the underlying mechanisms? And how can we measure them? Journal of New Music Research 33(3): 239-251.

Scherer K, Zentner M. 2001. Emotional effects of music: production rules. In Music and Emotion, Juslin P, Sloboda I (eds). Oxford University Press: Oxford; 361-392.

Schmitt B. 1999. Experiential marketing. Jonrnal of Marketing Management 15: 53-67.

Scollen RJ. 2008. Regional voices talk theatre: audience development for the performing arts. International Joumal of Nonprofit and Voluntary Sector Marketing 13(1): 45-56.

Seiders K, Voss G, Grewal D, Godfrey A. 2005. Do satisfied customers buy more? Examining moderating influences in a retailing context. Journal of Marketing 69: 26-43.

Spreng R, Mackoy R. 1996. An empirical examination of a model of perceived service quality and satisfaction. Joumal of Retailing 72(2): 201214.
Spreng R, Olshavsky R. 1992, A desires-as-standard model of consumer satisfaction: implications for measuring satisfaction. Joumal of Consumer Satisfaction Dissatisfaction, and Complaining Behavior 5: 45-54.

Tajtákova M, Arias-Aranda D. 2008. Targeting university students in audience development strategies for opera and ballet. The Service Industries Journal 28(2): 179-191.

Teas RK. 1993. Expectations, performance evaluation, and consumers' perceptions of quality. Journal of Marketing 57: 18-34.

Towse R. 2003. Opera. In A Handbook of Cultural Economics, Towse R (ed.). Elgar: Cheltenham; 342-348.

Vogel H. 2001. Entertainment Industry Economics, A Guide for Financial Analysis. Cambridge University Press: Cambridge.

Voss $Z$, Cova V. 2006. How sex differences in perceptions influence customer satisfaction: a study of theatre audiences. Marketing Theory 6(2): 201-221.

Walker-Kuhne D. 2001. Building community-based audiences for the arts. Part 1 and 2. http:// www.artsmarketing.org [May 24, 2008].

Watts BL, Messe LA, Vallacher RR. 1982. Toward understanding sex differences in pay allocation: agency, communion, and reward distribution behavior. Sex Roles 8(12): 1175-1187.

Woods W. 1960. Psychological dimensions of consumer decision. Journal of Marketing 24: 1519.

Zillmann D. 1994. Mechanisms of emotional involvement with drama. Poetics 23: 33-51.

Zwingmann $C$, Wirtz $M$, Mueller $C$, Koerber $J$, Murken S. 2006. Positive and negative religious coping in German breast cancer patients. Journal of Bebavioural Medicine 29(6): 533-547. 